\title{
Perceived Value, Social Bond, and Switching Cost as Antecedents and Predictors of Customer Loyalty in the B2B Chemical Industry Context: A Literature Review
}

\author{
Andreas Samudro ${ }^{1}$, Ujang Sumarwan ${ }^{2}$, Eva Z. Yusuf ${ }^{1} \&$ Megawati Simanjuntak ${ }^{2}$ \\ ${ }^{1}$ Graduate School of Management and Business, Bogor Agricultural University, Indonesia \\ ${ }^{2}$ Department of Family and Consumer Science, Graduate School of Management and Business, Bogor \\ Agricultural University, Indonesia
}

Correspondence: Andreas Samudro, Graduate School of Management and Business, Bogor Agricultural University, Indonesia.

Received: August 2, 2018 Accepted: August 21, 2018 Online Published: November 24, 2018

doi:10.5539/ijms.v10n4p124 URL: https://doi.org/10.5539/ijms.v10n4p124

\begin{abstract}
Industries have been emphasizing customer loyalty to ensure business sustainability. A lot of constructs influence customer loyalty, and this paper focuses on perceived value, social bond, and switching cost. What is actually behind customer's retention with the firms becomes exciting topics to be explored since firms will employ the best strategy to retain customers, either through offering superior value, investing in a relationship, or in setting up switching costs. This study is designed to develop integrative constructs of customer loyalty and investigates their antecedents using the literature review method. Perceived value tends to be evaluated from an economic benefit perspective since this paper refers to some business practices in chemical industries that concern cost. Purposely, to achieve this economic value, both firms and customers need to work closely, transparently, and cooperatively since the beginning; hence, it needs an interpersonal relationship between parties. With more transferred information from the customer and more transparent communication, firms will be able to identify the customer's need and deliver tailored superior value. This literature review finds that excellent value and the social bond become financial and relational switching costs for the customer. By understanding antecedents of loyalty, a firm can develop a social bond, superior value, and set up switching costs to create loyalty and build a sustainable business relationship.
\end{abstract}

Keywords: perceived value, social bond, switching costs and customer loyalty

\section{Introduction}

In the past empirical study, some researchers have described the importance of long-term relationships (Al Hawari \& Ward, 2006; Gupta, Lehmann, \& Stuart, 2004; Reinartz \& Kumar, 2002). A firm will get benefits with customer retention or loyalty since it influences better financial performance outcome (Evanschitzky \& Wunderlich, 2006; Gummesson, 2004; Lindgreen \& Wynstra, 2005; Ravald \& Grönroos, 1996; Reichheld, Markey, R. G., \& Hopton, 2000; N. Sharma \& Patterson, 1999). With high loyalty, a firm can improve performance by increasing revenue, reducing customer acquisition costs, and lowering cost of repeat purchase. These lead to better profitability (Lam, Shankar, Erramilli, \& Murthy, 2004). Purposely to have long-lasting relationships, firms have to focus on maintaining and enhancing the relationship with existing customers (Egan \& Harker, 2005; Eiriz \& Wilson, 2006; Harker \& Egan, 2006). The pursuit of improved relations seems to be more appropriate in the B2B context than in a more fragmented market as B2C context (Blut, Frennea, Mittal, \& Mothersbaugh, 2015; Chang, Wang, Chih, \& Tsai, 2012). KPMG Nunwood Consulting Limited (a worldwide consulting firm and a subsidiary of KPMG Holdings Limited) describes that the key success factor of the B2B business world lies in the strength of relationships with customers (KPMG-Nunwood, 2017). If the product tends to be a commodity, then relationship marketing is not sufficient. Relationship marketing fits more complex products that even need more tailor-made specifications (Kotler, 2005). This concept contradicts the past study of social bonding, which is not relevant to a more complex buying situation (Han, Wilson and Dant, 1993). This literature review refers to Kotler's concept, especially the implication of relationship marketing in a chemical industry with more complex products. This practical implication of the literature study in the chemical industry 
is extending past empirical research of B2B relationship marketing. Focusing on three critical constructs as perceived value, social bond, and switching cost, this paper explores how the practical implications of these three constructs in the chemical industry would influence customer loyalty.

\section{B2B Communication}

In B2B relationship context, either between manufacturers or between manufacturer and distributor, the relationship is managed by a lead person with the team get involved along the process (Hollyoake, 2009), as operations, finance, sales, and logistic. Mummalaneni (Mummalaneni, 1987) has even identified buyer-seller relationships at three different levels: the corporate level, the intermediate level, and the individual level, which is between specific members of the two organizations. Intensive communication and relationship investment will help to intensify relations in general, and at the individual level, it will even transform the relationship into a close personal relationship or create a social bond. This close relationship between the two parties would result in positive benefits for both parties. There would be transparent information transfer about what matters, and about preferences and needs of the customer. A firm can produce products and services based on this information, so competitors will find it challenging to entice customers; in another word, switching costs appear as a result (Pine II, Peppers, \& Rogers, 1995). A close personal relationship will create advantages for both parties through mutually beneficial cooperation. A good quality relationship can be used as a strategic tool for non-price competition instruments (Ural, 2009).

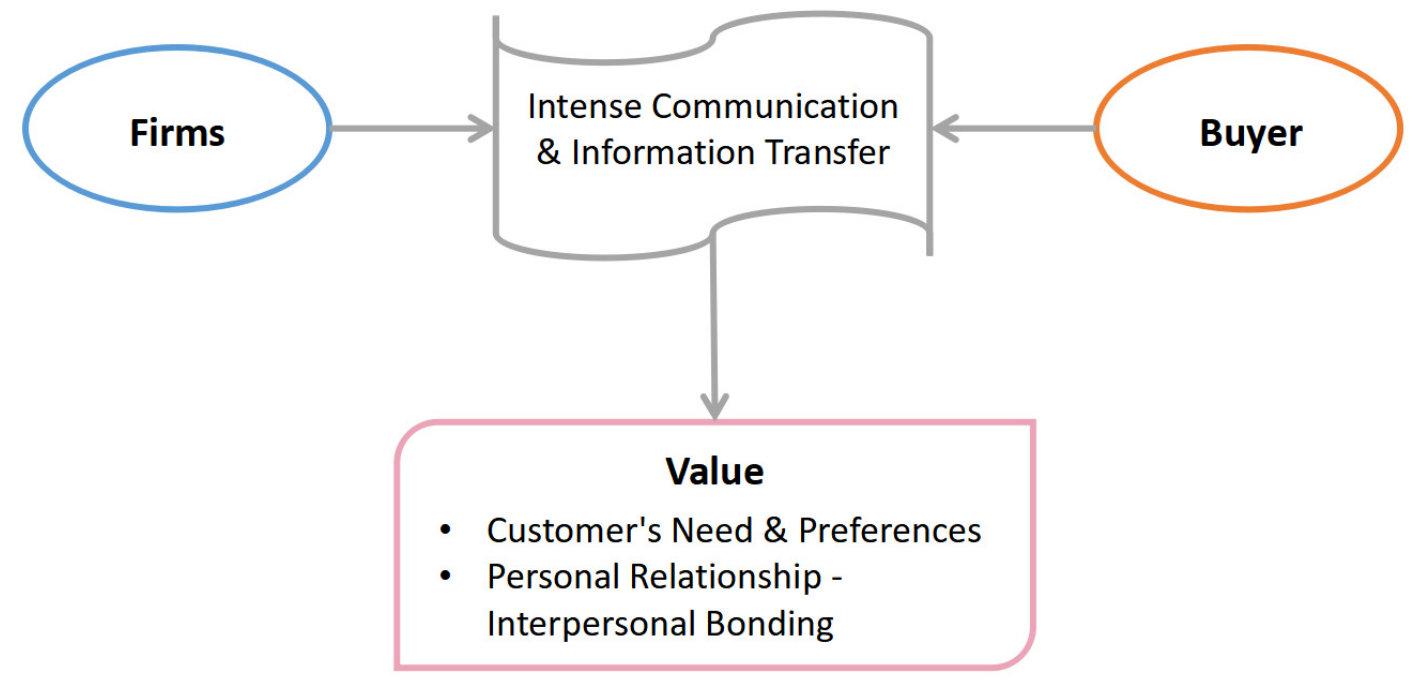

Figure 1. Value prediction through B2B-intensive communication

\section{Perceived Value}

Heskett et al. (Heskett, Jones, Loveman, Sasser, \& Schlesinger, 1994) define the concept of customer value as a comparison between what the customer wants to get and to give. Other researchers conducted studies using different terminology_-"perceived value" rather than "customer value," with a definition of perceived value as the ratio or trade-off between total benefit received to total sacrifices (Buzzell, Gale, \& Gale, 1987; Woodruff, 1997). Sharma et al. (Sharma, Krishnan, \& Grewal, 2001) stress the importance of superior value in creating customer loyalty. From the classical point of view, two components develop perceived value; the first component is received benefits as economic, social, and relationship, and the second component is sacrifices in price, time, effort, risk, and convenience (Cronin, Brady, Brand, Hightower, \& Shemwell, 1997; Grewal, Monroe, \& Krishnan, 1998; Oh, 2003). This view supports Ravald and Gronroos (Ravald \& Grönroos, 1996) who place customer-perceived value-formulation as a core solution, with additional services, and then compare it with price and relationship costs. Hence, firms can increase value either by reduced sacrifice from maintaining benefits or increased benefits from preserving sacrifice.

Other researchers have looked at perceived values from a different angle, compared with the classical view. For example, Sheth and Sharma (Sheth \& Sharma, 1997) describe value development between supplier and customer as developing relationship effectiveness. This concept depends on a single supplier instead of multiple suppliers. With the single-supplier concept, both parties can avoid uncertainty and minimize cost at the same time or 
receive even better product or service quality. Konhäuser (Konhäuser, 2007) supports the value expectation match model. This model introduces value perspectives from both sides, the seller and supplier. In other words, value creation cannot be generated by only one party. The value to the customer should match with the perceived value of the supplier; on the other side, the value to the supplier should match with the perceived value from the customer. There must be mutual benefits in any business B2B relationship, purposely to sustain a long-term business. In the case of relationship effectiveness, a customer will work closely and transparently with a supplier, and there must be particular added value as a target. This added value would be the best benefit a customer can get; on the other side, supplier will get continuity and sustainable business with a single supplier privilege. Both parties should enjoy long-term and mutual benefits with this cooperation.

Fiol et al. (Callarisa Fiol, Bigne Alcañiz, Moliner Tena, \& García, 2009) describe perceived value as influencing loyalty directly in the B2B context. In this study, Fiol et al. put two different analyses: first, respondents who have five or more suppliers, and second, respondents who have less than five suppliers. In the case of a company with less than five suppliers, perceived value influences loyalty relatively stronger than a company with five or more suppliers. In other words, the more suppliers firms have, the more possibility for customers to switch to other alternatives. Lam et al. (Lam et al., 2004) find that perceived value influences loyalty directly. This study is in the B2B service context, whose two dimensions and two most commonly service attributes are reliability and customization (Zeithaml, 2000). Service tends to be more customized than tangible products. Hence, once a customer fits the service provided by a supplier, this differentiated value seems to become a bonding element in the relationships.

\subsection{Perceived Value in Chemical Industry}

In the empirical study, Walter et al. (Walter, Ritter, \& Gemünden, 2001) explain that both customers and suppliers can work together to develop new tailored products and services. Purposely to accomplish direct monetary value creation, a customer should be more transparent with the supplier to get better solutions. In the business article of chemical industries, Anderson et al. (J. C. Anderson, Narus, \& van Rossum, 2006) describe value proposition, in terms of cost-saving for customers with the target to ensure that suppliers' offering outmatches competitors on the criteria that most matter to customers. In the B2B context, cost-saving and quality enhancement are the most important for the industry, including the chemical industry. Anderson et al. (J. C. Anderson et al., 2006) address a few cases as follows: chemical resin manufacturer deepens its understanding of paint industry-customer concern with setting up a team to conduct research. The labor cost is the top portion of the contractor cost structure; meanwhile, the paint materials are only $15 \%$ of the total cost. This team identifies customers' needs to enhance paint performance with a trade-off to share the monetary benefits through selling price increases. The resin can help the paint manufacturer to produce architectural coatings with higher film build and help the contractor to paint and dry faster. Hence, it helps the contractor to save on expensive labor costs. Finally, each party can enjoy the monetary benefits. The resin manufacturer can get a $40 \%$ price premium. The coating industry gets to benefit by increasing the selling price. Meanwhile, the contractor enjoys labor cost savings.

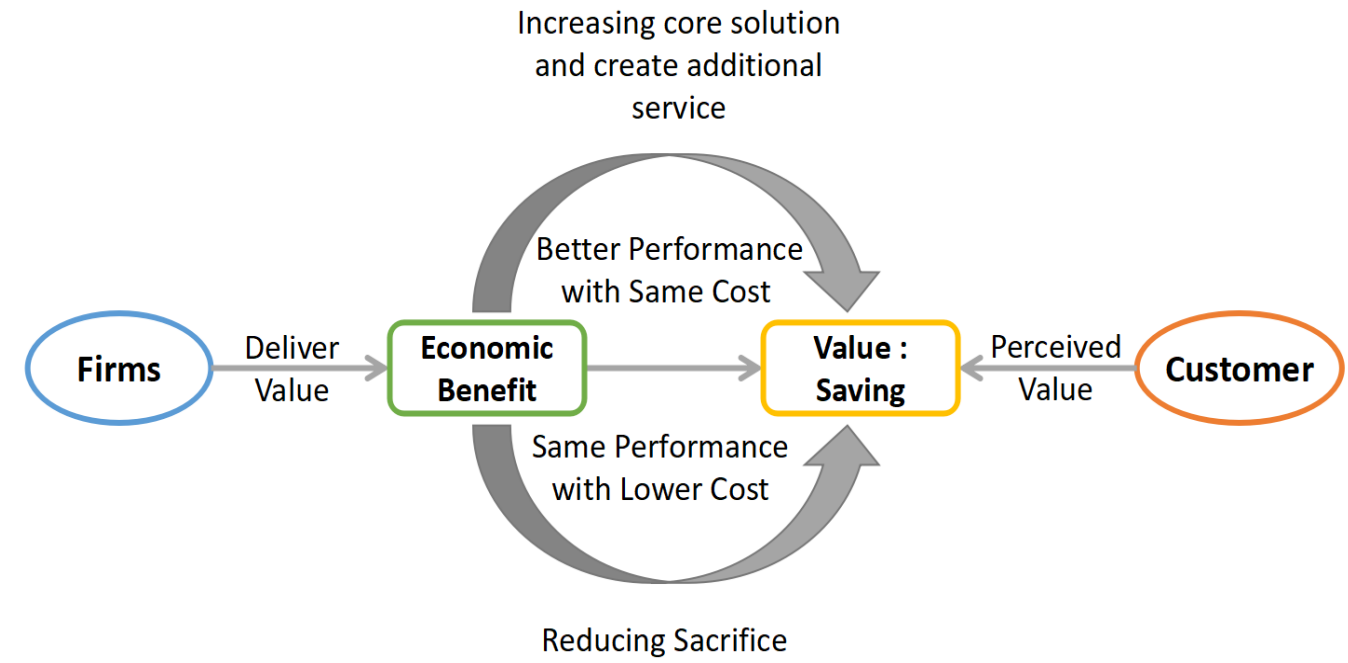

Figure 2. Value creation in single-supplier B2B relationships 
Another example of this case is Akzo Nobel, a worldwide chemical manufacturer. Akzo Nobel conducted a two-week pilot study on a prospect's plant in order to get better quality performance of a high-purity metalorganics product. This study suggested a lowered energy and lowered maintenance cost solution. As stated in a study by Mummalaneni (Mummalaneni, 1987), the corporate and personal levels of both parties should work and cooperate. This project involved many people across departments: from technical, laboratory, purchase, finance, and sales teams. With more complex quality issues, the cooperation between supplier and buyer in chemical manufacturers tends to be focused on few-, or even single-supplier policies.

Konhäuser (Konhäuser, 2007) finds perceived value as a critical driver for long-term relationship and loyalty. Ideally, the value to a customer should match with the perceived value of a supplier, and value to the supplier does match the perceived value from the customer. The more sellers and customer share their value, the stronger their relationship will be. From the past studies, some researchers avoura from a buyer's perspective (Flint, Woodruff, \& Gardial, 2002; Lapierre, 2000; Parasuraman, 1997; Ulaga \& Eggert, 2006), and the others are from a seller's perspective (Möller \& Törrönen, 2003; Simpson, Siguaw, \& Baker, 2001; Walter et al., 2001). This concept fits the business practice in the chemical industry, which is both parties working together share their info, data, and knowledge in a transparent environment, purposely to get shared value (chemical solution and profit sharing) as mutual benefits for both parties (Anderson et al., 2006). In empirical studies, some researchers find perceived value influencing loyalty positively (Abdolvand \& Norouzi, 2012; Lam et al., 2004; Parasuraman \& Grewal, 2000; Rauyruen \& Miller, 2007; Walter, Mueller, \& Helfert, 2000; Zeithaml, 1988).

\section{Social Bond}

In their study, Chattananon and Trimetsoontorn (Chattananon \& Trimetsoontorn, 2009) describe bonding as a dimension of a business relationship, which makes a single act between two parties the desired goal. This bonding will influence the perceptions and avourable toward each other (Bendapudi \& Berry, 1997). A social bond is the degree of personal friendship and liking shared by seller and buyer (Wilson, 1995). Ravald and Gronroos (Ravald \& Grönroos, 1996) state that firms should be more focused on customers. Hence, a firm should either increase benefits, include relationship benefits or reduce sacrifice, and provide relationship sacrifice for customers. This study was followed and supported by Rust et al. (Rust, Danaher, \& Varki, 2000), who indicate that firms should focus more on customers, i.e., on customers' long-term contribution to the firm's performance. This perspective tends to concentrate on future sales and profits forecasts from customers. KPMG Nunwood (KPMG-Nunwood, 2017) consulting firm supports the view that firms should be more focused on people, especially the customer experience, than on products. Thus, successful firms will capitalize on the moment that matters to purposely enhance relationships. KPMG Nunwood's business paper introduces six pillars of customer experience, and four of the components are related to personal bonds - personalization, integrity, empathy, and expectations.

Some researchers describe broader types of bonding (Dwyer, Schurr, \& Oh, 1987; Ford, 1980; Hakansson, 1982; Müller \& Wilson, 1988; Wilson \& Mummalaneni, 1986), which are social, technological, knowledge, planning, legal, and economic bonds. Liljander and Strandvik (Liljander \& Strandvik, 1995) add another four types of bonds - geographical, cultural, ideological, and psychological. In the information technology environment B2B study, $\mathrm{Li}$ et al. (Li, Tseng, \& $\mathrm{Lu}, 2007$ ) find social bonds with three dimensions: familiarity bond, commitment bond, and structural bond. The structural bond is essential to keep the long-term relationship; meanwhile, both familiarity and commitment bonds are somewhat necessary. Smith (Smith, 2009) develops hypotheses with social bonds, structural bonds, and functional bonds as the bases for relational outcomes or relationship quality. Smith refers to the old concept of Turker that some factors are creating functional bonds, for example, economic, strategic, technology, product, and service benefits. Smith finds that the social bond influences loyalty positively. Structural bonds are ties relating to the structure, governance, and institutionalization of norms in a relationship (Wilson, 1995).

In the B2B relationship, some complex industries need a commitment from the customer since it requires investment to support product and service applications, as in computer systems, manufacturing equipment, telecom equipment, and medical devices (Stender \& Ritz, 2006). A related complex industry is chemical products and solutions, where supporting equipment investment is necessary (Blut, Evanschitzky, Backhaus, Rudd, \& Marck, 2016). In a B2B chemical industry study, Blut et al. (Blut et al., 2016) test hypotheses and a model that separately observe switching cost and satisfaction to ensure that the observed repeat purchase is influenced more by relational switching costs instead of satisfaction. From this study, it seems that firms need to ensure that customers stay because of developed interpersonal bonding rather than high switching costs. 
In the empirical study of the chemical industry, Joseph and Unnikrishnan find that social bonds positively influence customer loyalty (Joseph \& Unnikrishnan, 2016). This study supports the previous research by Narteh et al. (Narteh, Agbemabiese, Kodua, \& Braimah, 2013) that finds a strong influence between social bonds and customer loyalty. Structural and social bonds were found to be effective influencing customer loyalty compared with financial bonds. This study places suggestions to use more structural and social bonds instead of financial bonds since it is easy to imitate financial bonds. Stender and Ritz (Stender \& Ritz, 2006) identify emotional intensity to be effectively influencing loyalty, and this emotional intensity captures the affective nature of a relationship. This emotional intensity is part of a social bond in terms of an affective factor. The psychological element is also described by McMullan and Gilmore (McMullan \& Gilmore, 2008) in their empirical study, which is a social domain incorporates emotional content, sentiments of allegiance and faithfulness.

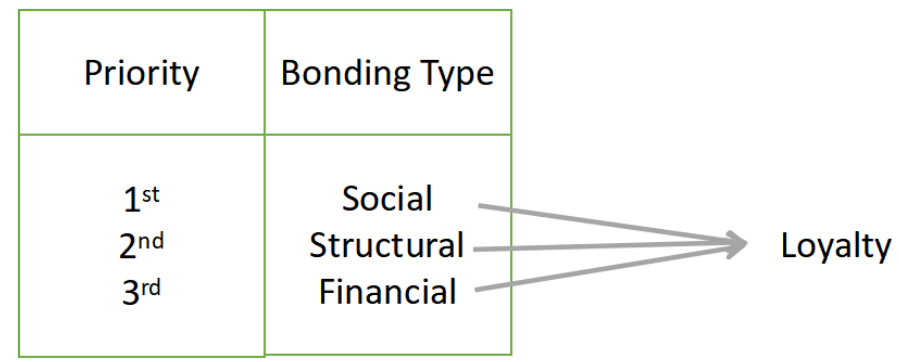

Figure 3. Relationship between bonding to loyalty based on priority

In the past study, Gounaris (Gounaris, 2005) and Wilson and Mummalaneni (Wilson \& Mummalaneni, 1990) explain social bond from both affective and avourable perspective, whereby social bonding holds buyers and sellers firmly in a personal sense, includes personal interactivity and personal closeness. McMullan and Gilmore (2008) find that personal relationships are a critical driver for choosing a company, more than products (McMullan \& Gilmore, 2008). Hence, social bonds are more influential in acquiring loyalty than the product or service itself. This study attempts to avoura the determining factors of B2B relationship quality in the financial sector. It might explain why the personal relationship is more important than the product itself since there is a similarity of product offerings among players in the financial sector. The differentiation is actually on personal service.

In their empirical study of the social business relationship, Linde and Holmqvist (Linde \& Holmqvist, 2011) define five critical concepts as crucial in the relationship between manufacturer and distributor, and one of them is personal attachment. This study finds that interaction outside the business is one factor influencing tied relationships. Gremler et al. (Gremler, Gwinner, \& Brown, 2001) explain that a company with a relationship-focused strategy should design its relationship environment so that it enables both formal and informal interaction opportunities between employees and customers. There should be a company relationship-supporting program to encourage and enhance relationships between employees and customers to create bonding and loyalty intentionally. This personal bond concept is also in line with the previous study, which found that strong personal bonds tend to maintain and strengthen the business relationship and influence loyalty (Wilson, 1995). Wilson (1995) defines social bonding as the degree of mutual friendship and liking shared by seller and buyer. Mummalaneni (Mummalaneni, 1987) finds close personal relationships mostly avourable to the firm, whereby the customer commits to the relationship. A relational bond will influence the customer's loyalty and indirectly result in better firm performance (Wulf, Odekerken-Schröder, \& Iacobucci, 2001). Anttila (Anttila, 2013) finds that personal relationships influence loyalty in the B2B context. There should be personal bonds as a result of personal relationships. Caruana (Caruana, 2003) identifies that customer relationship quality will influence a customer to remain with the firm; in other words, the customer would not display switch intention to other alternatives and would keep loyal to the firm. Hewett et al. (Hewett, Money, \& Sharma, 2002) find a positive relationship between strong relationships and a firm's profitability since buyers are likely to purchase from companies they trust and are committed to. In more complex chemical products and solutions, deeper cooperation and a more transparent environment are necessary for both parties to get a solution and mutual benefits. Since close communication would be intense, the personal relationship should follow and accelerate to reach the goal. 


\section{Switching Costs}

Firms develop customer loyalty partly by creating switching costs (Gremler, 1995). In the dissertation, Gremler describes switching costs as real monetary and non-monetary costs. Jones et al. (Jones, Mothersbaugh, \& Beatty, 2002) define switching costs from buyers' perceived as all perceived, anticipated and or experienced costs with switching relationships from existing seller to other alternatives (Burnham, Frels, \& Mahajan, 2003; Jones et al., 2002). This Jones et al. definition is the most commonly cited in the empirical study. Jones et al. (Jones, Reynolds, Mothersbaugh, \& Beatty, 2007) describes switching costs further as the sacrifices or penalties consumers feel they may incur as consequences in moving from one provider to the next. This literature review focuses on buyers' perceived switching costs and excludes seller perception.

Burnham et al. (Burnham et al., 2003) in their empirical B2C study initially distinguish switching costs into procedural, relational switching costs and financial costs. The third type of switching cost is categorized by Jones et al. (Jones et al., 2007) as the lost benefits costs. Guiltinan (Guiltinan, 1989) supports this study, which is switching costs, including financial costs, relational costs, and time and effort costs. In their empirical research of switching costs impact in chemical product and solution B2B industry, Blut et al. (Blut et al., 2015) find relational switching costs have a positive effect on the customer's cross-buying behavior across firm's product and service categories, and also firm's share of wallet. In the other direction, relational switching costs have a negative effect on the customer's switching behavior. As seen in some empirical studies, researchers use the same category, essence, and facets of switching costs. Some of them are B2B studies (Dick \& Basu, 1994; Himanka, 2017; Kim, Kliger, \& Vale, 2003; Klemperer, 1995; Lam et al., 2004; Pick \& Eisend, 2014), and some are B2C studies (Chebat, Davidow, \& Borges, 2011; Jones, Mothersbaugh, \& Beatty, 2000; Jones et al., 2007).

Table 1. Eight facets and three types of B2B and B2C switching costs

\begin{tabular}{|c|c|c|c|c|c|c|}
\hline \multicolumn{3}{|c|}{$\begin{array}{c}\text { Procedural } \\
\text { Switching Costs }\end{array}$} & \multicolumn{2}{|c|}{$\begin{array}{c}\text { Financial } \\
\text { Switching Costs }\end{array}$} & \multicolumn{2}{|c|}{$\begin{array}{c}\text { Relational } \\
\text { Switching Costs }\end{array}$} \\
\hline $\mathrm{B} 2 \mathrm{~B}$ & & $\mathrm{~B} 2 \mathrm{C}$ & $\mathrm{B} 2 \mathrm{~B}$ & $\mathrm{~B} 2 \mathrm{C}$ & $\mathrm{B} 2 \mathrm{~B}$ & $\mathrm{~B} 2 \mathrm{C}$ \\
\hline Uncertainty costs & $\cdot$ & Economic risk & Sunk costs & - $\quad$ Benefit & $\begin{array}{ll} & \text { Personal }\end{array}$ & $\begin{array}{ll} & \text { Personal }\end{array}$ \\
\hline Pre-switching & costs & & Lost & loss costs & relationship loss & relationship loss costs \\
\hline search and evaluation & $\cdot$ & Evaluation & performance costs & - $\quad$ Monetary & costs & - $\quad$ Brand \\
\hline costs & costs & & & loss costs & - $\quad$ Brand & relationship loss costs \\
\hline Post-switching & $\bullet$ & Setup costs & & & relationship loss & \\
\hline $\begin{array}{l}\text { behavioral and cognitive } \\
\text { costs }\end{array}$ & $\begin{array}{l}\cdot \\
\text { costs }\end{array}$ & Learning & & & costs & \\
\hline - $\quad$ Setup costs & & & & & & \\
\hline
\end{tabular}

Both empirical studies by Burnham et al. (Burnham et al., 2003) and Blut et al. (Blut et al., 2015) use switching costs to construct [a table] with the same dimensions. This switching costs construct has eight facets, with details as shown in Table 1. Dick and Basu (Dick \& Basu, 1994) describe the domain of switching costs as encompassing non-monetary (time and effort) and monetary expense costs. From the above table, a procedural switching cost involves the expenditure of time and effort. A financial switching cost involves quantifiable financial loss; meanwhile, a relational switching cost involves psychological or emotional discomfort due to the breakup of bonds. Financial switching costs are measured in monetary loss precisely because of the firm's switch to a new supplier. Procedural and relational switching costs tend to be more intangible in value, or a non-monetary cost, as they exist as time and effort to get new suppliers or discomfort feeling like a new customer (Dick \& Basu, 1994; Kim et al., 2003; Klemperer, 1995). The procedural switching cost category covers time and effort costs; for instance, a customer may have developed a routine and procedures for dealing and delivering the product and services from the supplier. Once the relationship breaks up, the customer must start from the beginning with the new seller (Heide \& Weiss, 1995; Jap \& Ganesan, 2000). Jones et al. (Jones et al., 2007) define switching costs as procedural costs, social switching costs which are the same as relational switching costs, and lost benefit costs which are the same as financial switching costs. From past research, all types of switching costs apply to both the B2B and B2C relationship contexts. Jones et al. (Jones et al., 2000) even refer to details elements of B2B switching cost for their empirical study of B2C services switching costs.

\subsection{Switching Cost, Dissatisfied Customer, and Implication in Chemical Industry}

Switching cost is a function to strengthen a relationship, the higher the switching cost, the less likely a customer is to switch supplier (Himanka, 2017). There are different types of switching costs, and some of them may have 
negative consequences. In their empirical study, White and Yanamandram (White \& Yanamandram, 2007) investigate factors that influence dissatisfied customers to keep purchasing in the B2B service context, and this study finds some elements as follows, the impact of alternatives providers, switching costs, interpersonal relationships, service recovery, and inertia. Since alternatives providers are not so attractive to be a replacement factor, then dissatisfied customer remains with the existing firms. Pick and Eisend support this study with a meta-analytic method of buyer's perceived switching cost (Pick \& Eisend, 2014). Pick and Eisend (2014) find market-related variables (alternatives and competition) as a critical driver and strongest influence factor on switching costs. If there is not much option from alternatives, a customer will dissatisfy with high switching costs. With high switching cost, dissatisfied customers have not the opportunity to switch supplier because additional cost is too expensive. Both (the lack of) alternative providers and high switching costs are on the top two reasons why dissatisfied customers remain with existing firms. In their empirical study, Grønhaug and Gilly (Grønhaug \& Gilly, 1991) found that even disappointed customers stay with their firms because of high switching costs. In other words, high switching costs force a customer to tolerate a provider's poor performance.

Lam et al. (Lam et al., 2004) find that switching costs have a positive effect on customer loyalty (patronage). The basis of this hypothesis is mostly monetary - that customers need to economize any costs incurred from switching to another provider. This study describes that dissatisfied customers have a tendency not to recommend their service provider to others, and there is a tendency for the customers to bad-mouth the provider. Selnes (1993) also finds that high switching costs influence customer loyalty. The switching cost category in this context relates to psychological, economic, and technical factors. It may seem to be a different terminology from the previous switching cost categories (relational, financial, and procedural), but the essence is the same. There is a slightly contradictory opinion about the switching cost effect, as explained by Blut et al. (Blut et al., 2015). They show that relational switching costs influence loyalty positively and firmly, financial switching costs do the reverse-influence loyalty negatively and small, and procedural switching costs have no influence on loyalty. Jones et al. (Jones et al., 2007) find that social or relational switching costs and lost benefits costs appear to bolster affective commitment or create positive nature of constraints from customers' perspective to switch other alternatives. Meanwhile, procedural switching costs appear to bolster calculative commitment or create negative nature of constraints from customers' perspective.

With respondents of chemical product and solution industry, the value proposition delivered by firms is usually in term of quality improvement and or cost saving. The successful chemical solution needs more transparent and cooperation between both parties during the process. Once both parties accomplish the project, which is delivering value to the customer in term of cost saving and or quality improvement, then it is becoming financial switching cost for a customer to move to other alternatives. Some value accomplishment cases in the business market are chemical resin manufacturers. Akzo Nobel chemical manufacturer is successfully lowering energy and maintenance cost with enhancing the performance of its high-purity metal organic product (J. C. Anderson et al., 2006). In this industry, once customers' perspective of product and or service performance is positive, it is becoming switching costs and procedural costs. Searching, evaluating and selecting other alternatives are time, effort and expense consume. It is not easy for a competitor to entice a customer once both parties accomplish their value target. The value share must be fair for both parties; otherwise, the disadvantaged party will not be committed to a long-term relationship.

\section{Customer Loyalty}

In every business context, customer loyalty is the company's greatest concern, and having long-term relationships is the highest priority for most supplier companies (Barroso \& Picón, 2012). With long-term and stable relationships, a company will benefit from increased profits and other positive effects and be able to withstand tough competition (Hewett et al., 2002). Dick and Basu (Dick \& Basu, 1994) find loyalty to be an essential objective in the industrial relationship. This relationship type is called vendor loyalty. From the attitudinal perspective, Briggs et al. (Briggs, Landry, \& Daugherty, 2007) describe loyalty as a buyer's overall commitment to a product, service, brand or organization. From the ehavioural viewpoint, Rauyruen and Miller (Rauyruen \& Miller, 2007) describe loyalty as a business customer's willingness to repurchase a product and/or service and maintain a relationship with the provider. Oliver (1993) studies a more significant spectrum of attitudinal, ehavioural, and cognitive dimensions. Loyalty is a commitment to rebuy a preferred product or service in the future from the same brand, despite there being situational influences or marketing efforts to cause a switch action (Oliver, 1993). In many past researches loyalty manifests, itself becoming a variety of behaviors such as recommendation to others, word of mouth, patronizing or advocating vendors, retention, and repurchase intentions (Dwyer et al., 1987; Fornell, 1992; Himanka, 2017; Jones et al., 2007; Lam et al., 2004). 
Loyalty will increase a firm's performance by increasing revenue, reducing acquisition costs, and lowering repeat order costs (Himanka, 2017).

\subsection{Perceived Value, Social Bonds, and Switching Cost as Predictors of Customer Loyalty}

As in many past empirical studies, some factors can influence loyalty as perceived value, social bond, and switching cost. Switching costs could be from the negative source of constraints as procedural switching cost, but it might be from the definite source of restrictions as social (relational) and lost benefits (financial) switching costs (Jones et al., 2007). This concept is supported by Himanka (Himanka, 2017), with the finding that switching costs are influencing loyalty, either with positive or negative consequences. Smith (Smith, 2009) finds that social bonds influence loyalty positively. Gremler et al. (Gremler et al., 2001) find relationship focus as an essential firm to develop. A firm needs to encourage employees to have a personal relationship with customers, even with a formal and informal relationship program. Interaction will create familiarity, personal bonds, and caring between two parties as well as positive effects (Anttila, 2013). Many past studies suggest that companies keep the relationship because of a strong social bond or high switching cost, other word loyalty could be driven either by social bonds or high switching cost (de Ruyter, Moorman, \& Lemmink, 2001; Gilliland \& Bello, 2002; Liu, 2006). From Fiol et al.'s (Callarisa Fiol et al., 2009) study, the fewer suppliers firms have, the more loyalty tends to be. Anderson et al. (J. C. Anderson et al., 2006) even propose a single supplier to proceed with customers' solution, especially in the more complex products as in the chemical industry. This cooperation would generate a sustainable long-term relationship. Konhäuser (2007) introduces the value expectation match for both sellers and buyers. As long as the value perspectives match from both sellers and buyer perspectives, then both parties will enjoy long-term benefits; hence, loyalty will be accomplished (Konhäuser, 2007). In the chemical business, J. C. Anderson et al. (2006) describe value creation by seller and buyer. The share of saving value will be mutual benefits for parties and enhance customer loyalty. Both parties will remain in the relationship as long as each party gets benefits (Anderson et al., 2006).

If loyalty comes from high switching cost, a dissatisfied customer is forced to stay in business, and then there would be a tendency of adverse consequences from a customer, either resistance to recommend to others or even to have a bad mouth (Lam et al., 2004). Dissatisfied customers tend to tolerate a disadvantage as a partner for only a temporary period (E. Anderson \& Weitz, 1992). Two dimensions of switching costs are the economic dimension, for procedural and financial switching costs, and the psychological dimension for relational switching costs, and in terms of both these dimensions, firms can manage customer perceptions of switching costs to foster retention (Jones et al., 2000). Loyalty (patronage) is influenced positively by switching costs (Lam et al., 2004). In its business paper, KPMG Nunwood introduces six pillars of customer experience, one of which is switching cost type as a critical driver for customer loyalty (KPMG-Nunwood, 2017). This sixth pillar is a phenomenon in switching costs from a business practice standpoint.

\section{Antecedents and Constructs of Loyalty}

Many relationships involve antecedents, judgments, and consequences of loyalty. The proposed predictors of loyalty drive the relationships.

\subsection{Perceived Value}

Rational Judgement Towards Value

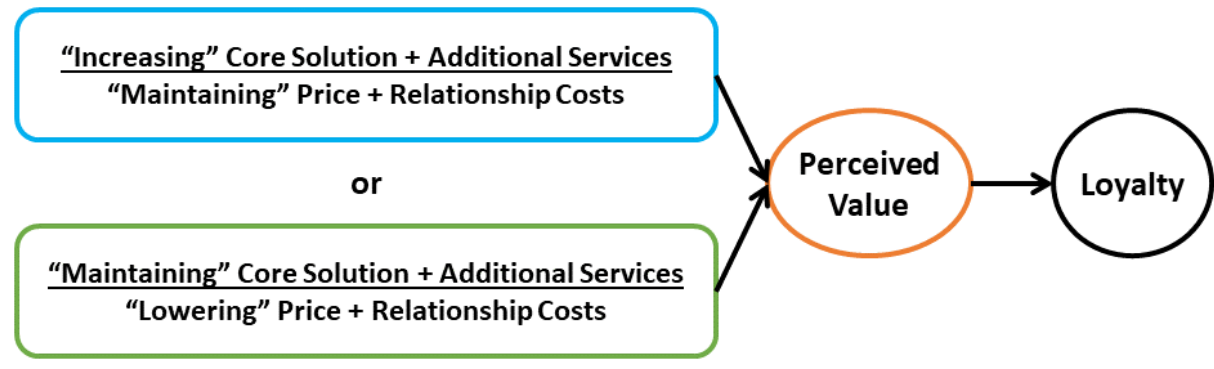

Figure 4. Antecedents of perceived value and loyalty 
In the chemical industry context, cost savings or enhanced performance/quality of products and services becomes a value match between the seller and buyer. This value will become the positive switching cost for customers to replace the products and services with alternatives.

\subsection{Social Bond}

With formal and informal communication established from the beginning, this intensive communication will enhance the relationship between the parties. Sellers will get to know what is actually needed and preferences of the customers. Meanwhile, from an affective perspective, customers will choose from the people they know.

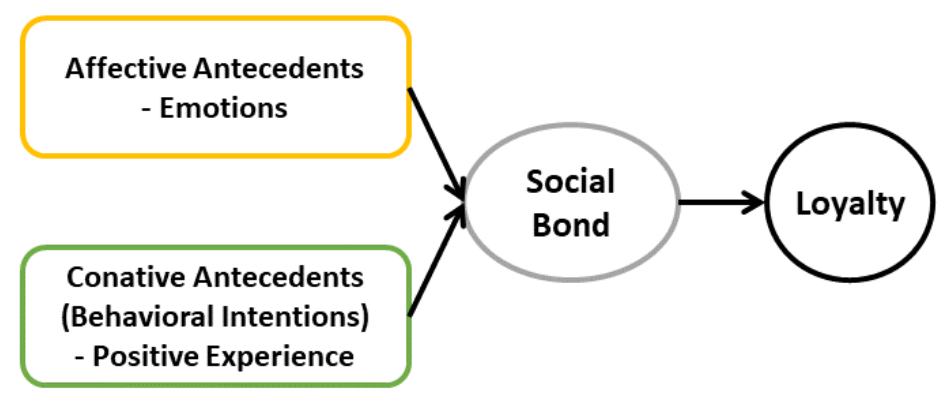

Figure 5. Antecedents of social bond and loyalty

\subsection{Switching Cost}

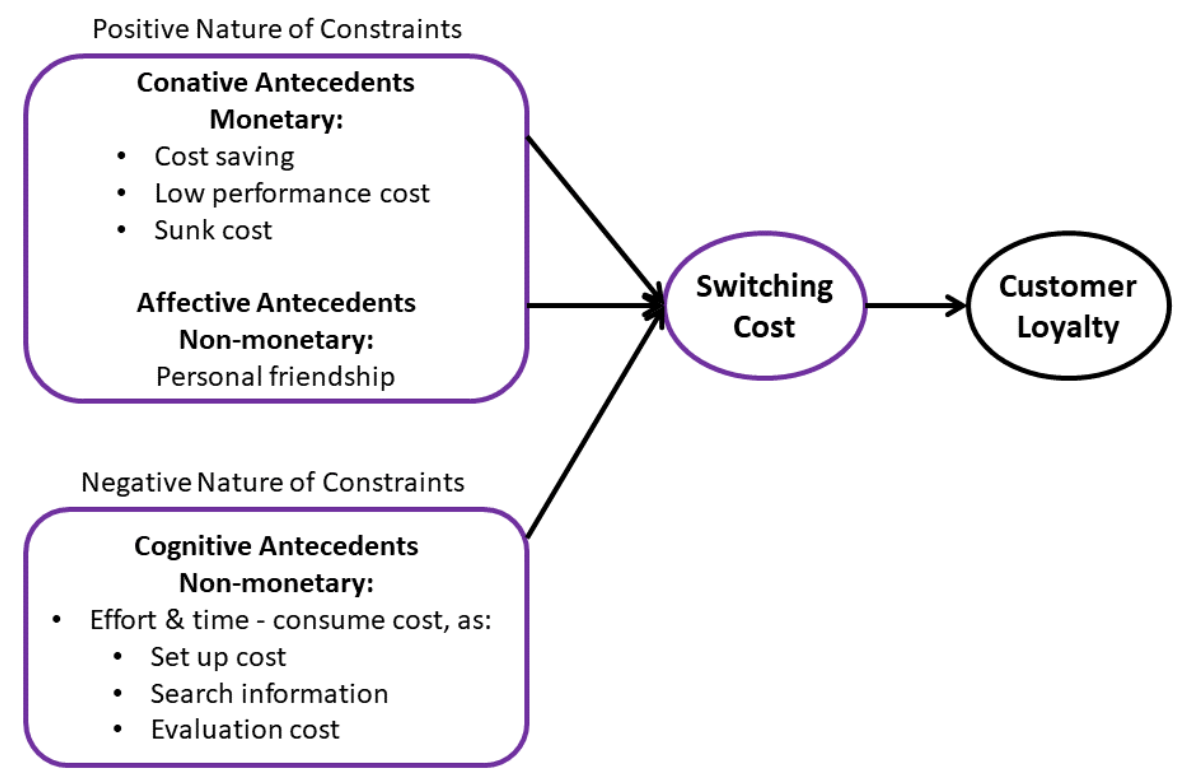

Figure 6. Antecedents of switching cost and loyalty

Financial and relational switching costs are positive sources of constraint for a customer to move to alternatives since it creates value saving. Procedural switching costs are negative sources of constraint for the customer to move since disappointed customers remain the relationship, although with poor performance. All switching cost types will influence loyalty in the same direction, although with different consequences.

\section{Conclusion}

In the B2B context, perceived value is a trade-off between the benefits delivered by seller and the sacrifice made by the buyer. Ravald and Grönroos (Ravald \& Grönroos, 1996) introduce customer perceived value in terms of relationship benefits and sacrifice. This concept is described with some chemical industry cases by J. C. Anderson et al. (2006), which is concerning saving benefit as value (J. C. Anderson et al., 2006). In the B2B chemical industry context, the perceived value base is more rational judgment. Saving is a core value to be 
achieved either by enhancing product quality at the same cost or by maintaining product quality at a lower cost. Accomplishing this objective requires more transparency and closer collaboration between firms and their customers. A firm needs to accelerate the relationship with its customers-make it a personal connection so that the customer feels free to actively participate in discussions on every detail of the firm's plans. A social bond needs to be built from the beginning through this project to achieve the savings objective. Once both parties accomplish the objective, this perceived value (to the customer) becomes a hard barrier for competitors to penetrate. All positive experiences with the firm's products and services contribute to the confidence level and positive emotions of the customer. In the end, the mutual benefits for both parties (i.e., the seller and buyer) and the strong social bond lead to loyalty.

Thus, in every business relationship, firms have to develop a favorable switching cost due to its effect on customer loyalty. Related to this, firms need to analyze and ensure which type of switching cost fits in their development of a relationship with customers. A positive switching cost comes from an excellent interpersonal relationship and cost saving instead of a high switching cost in terms of lost non-monetary (i.e., time and effort) costs. An excellent interpersonal relationship itself is a dimension of social bonding. In other words, a good interpersonal relationship and created value (cost saving) become the "real" switching cost from the customer's perspective. In the empirical B2B study of Blut et al. (2015) and the empirical B2C study of Burnham et al. (2003), the researchers and their teams found similarities in switching cost types-procedural, financial, and relational switching costs.

From a theoretical standpoint, empirical studies find switching cost to be a predictor of retention or loyalty (E. W. Anderson, 1994; E. W. Anderson \& Sullivan, 1993; Fornell, 1992). Firms need to manage customer perceptions of switching costs from a positive standpoint, purposely, to get retention or loyalty (Bendapudi \& Berry, 1997; Fornell, 1992). A robust social bond becomes a positive relational switching cost and a positive constraint for competitors to entice the customer. An excellent perceived value becomes a financial switching cost for the customer and increases the positive nature of constraints for competitors to penetrate the business. Unless a greater or proven value presents itself, both parties will remain in the relationship for an extended period. The procedural switching cost tends to be a negative constraint in the customer's view. With limited or even no product or service alternatives available, a customer will remain in the relationship even if disappointed. A high procedural switching cost is something a firm must avoid because it encourages customers to stay with poor performance. Once any alternative solution appears, the customer will leave the firm to go to another source. It is much better that customers want to stay in the relationship because of high value and strong social bonds than high procedural switching costs.

\section{References}

Abdolvand, M. A., \& Norouzi, A. (2012). The effect of customer perceived value on word of mouth and loyalty in B-2-B marketing. Research Journal of Applied Sciences, Engineering, and Technology, 4(23), 4973-4978.

Retrieved

from https://pdfs.semanticscholar.org/fce4/de3e455ec81821249bbfb97ab8007ab76ffd.pdf

Al-Hawari, M., \& Ward, T. (2006). The effect of automated service quality on Australian banks' financial performance and the mediating role of customer satisfaction. Marketing Intelligence \& Planning, 24(2), 127-147. https://doi.org/10.1108/02634500610653991

Anderson, E. W. (1994). Cross-category variation in customer satisfaction and retention. Marketing Letters, 5(1), 19-30. https://doi.org/10.1007/BF00993955

Anderson, E. W., \& Sullivan, M. W. (1993). The antecedents and consequences of customer satisfaction for firms. Marketing Science, 12(2), 125-143. https://doi.org/10.1287/mksc.12.2.125

Anderson, E., \& Weitz, B. (1992). The use of pledges to build and sustain commitment in distribution channels. Journal of Marketing Research, 29(1), 18. https://doi.org/10.2307/3172490

Anderson, J. C., Narus, J. A., \& van Rossum, W. (2006). Customer Value Propositions in Business Markets. Harvard Business Review, (March), 91-99. Retrieved from https://hbr.org/2006/03/customer-value-propositions-in-business-markets

Anttila, V. (2013). Value creation through planned communication and interaction in B2B relationships case: TDC Oy Finland. Retrieved from http://urn.fi/URN:NBN:fi:aalto-201305092090

Barroso, C., \& Picón, A. (2012). Multi-dimensional analysis of perceived switching costs. Industrial Marketing Management, 41(3), 531-543. https://doi.org/10.1016/j.indmarman.2011.06.020 
Bendapudi, N., \& Berry, L. L. (1997). Customers' motivations for maintaining relationships with service providers. Journal of Retailing, 73(1), 15-37. https://doi.org/10.1016/S0022-4359(97)90013-0

Blut, M., Evanschitzky, H., Backhaus, C., Rudd, J., \& Marck, M. (2016). Securing business-to-business relationships: The impact of switching costs. Industrial Marketing Management, 52(May), 82-90. https://doi.org/10.1016/j.indmarman.2015.05.010

Blut, M., Frennea, C. M., Mittal, V., \& Mothersbaugh, D. L. (2015). How procedural, financial and relational switching costs affect customer satisfaction, repurchase intentions, and repurchase behavior: A meta-analysis. International Journal of Research in Marketing, 32(2), 226-229. https://doi.org/10.1016/j.ijresmar.2015.01.001

Briggs, E., Landry, T. D., \& Daugherty, P. J. (2007). Patronage in continually delivered business service contexts. Journal of Business Research, 60(11), 1144-1151. https://doi.org/10.1016/j.jbusres.2007.04.005

Burnham, T. A., Frels, J. K., \& Mahajan, V. (2003). Consumer switching costs: A typology, antecedents, and consequences. Journal of the Academy of Marketing Science, 31(2), 109-126. https://doi.org/10.1177/0092070302250897

Buzzell, R. D., Gale, B. T., \& Gale, B. T. (1987). The PIMS Principles: Linking Strategy to Performance. Simon and Schuster.

Callarisa Fiol, L. J., Bigne Alcañiz, E., Moliner Tena, M. A., \& García, J. S. (2009). Customer loyalty in clusters: Perceived value and satisfaction as antecedents. Journal of Business-to-Business Marketing, 16(3), 276-316. https://doi.org/10.1080/10517120802496878

Caruana, A. (2003). The impact of switching costs on customer loyalty: A study among corporate customers of mobile telephony. Journal of Targeting, Measurement, and Analysis for Marketing, 12(3), 256-268. https://doi.org/10.1057/palgrave.jt.5740113

Chang, S.-H., Wang, K.-Y., Chih, W.-H., \& Tsai, W.-H. (2012). Building customer commitment in business-to-business markets. Industrial Marketing Management, 41(6), 940-950. https://doi.org/10.1016/j.indmarman.2011.11.026

Chattananon, A., \& Trimetsoontorn, J. (2009). Relationship marketing: A Thai case. International Journal of Emerging Markets, 4(3), 252-274. https://doi.org/10.1108/17468800910968418

Chebat, J.-C., Davidow, M., \& Borges, A. (2011). More on the role of switching costs in service markets: A research note. Journal of Business Research, 64(8), 823-829. https://doi.org/10.1016/j.jbusres.2010.10.003

Cronin, J. J., Brady, M. K., Brand, R. R., Hightower, R., \& Shemwell, D. J. (1997). A cross - sectional test of the effect and conceptualization of service value. Journal of Services Marketing, 11(6), 375-391. https://doi.org/10.1108/08876049710187482

De Ruyter, K., Moorman, L., \& Lemmink, J. (2001). Antecedents of commitment and trust in customer-supplier relationships in high technology markets. Industrial Marketing Management, 30(3), 271-286. https://doi.org/10.1016/S0019-8501(99)00091-7

Dick, A. S., \& Basu, K. (1994). Customer loyalty: Toward an integrated conceptual framework. Journal of the Academy of Marketing Science, 22(2), 99-113. https://doi.org/10.1177/0092070394222001

Dwyer, F. R., Schurr, P. H., \& Oh, S. (1987). Developing buyer-seller relationships. Journal of Marketing, 51(2), 11. https://doi.org/10.2307/1251126

Egan, J., \& Harker, M. (2005). Relationship Marketing: Shaking the Foundations: The Origins of Relationship Marketing. Sage Publications.

Eiriz, V., \& Wilson, D. (2006). Research in relationship marketing: Antecedents, traditions, and integration. European Journal of Marketing, 40(3/4), 275-291. https://doi.org/10.1108/03090560610648057

Evanschitzky, H., \& Wunderlich, M. (2006). An examination of moderator effects in the four-stage loyalty model. Journal of Service Research, 8(4), 330-345. https://doi.org/10.1177/1094670506286325

Flint, D. J., Woodruff, R. B., \& Gardial, S. F. (2002). Exploring the phenomenon of customers' desired value change in a business-to-business context. Journal of Marketing, 66(4), 102-117. https://doi.org/10.1509/jmkg.66.4.102.18517

Ford, D. (1980). The development of buyer - seller relationships in industrial markets. European Journal of Marketing, 14(5/6), 339-353. https://doi.org/10.1108/EUM0000000004910 
Fornell, C. (1992). A national customer satisfaction barometer: The Swedish experience. Journal of Marketing, 56(1), 6. https://doi.org/10.2307/1252129

Gilliland, D. I., \& Bello, D. C. (2002). Two sides to attitudinal commitment: The effect of calculative and loyalty commitment on enforcement mechanisms in distribution channels. Journal of the Academy of Marketing Science, 30(1), 24-43. https://doi.org/10.1177/03079450094306

Gounaris, S. P. (2005). Trust and commitment influences on customer retention: Insights from business-to-business services. Journal of Business Research, 58(2), 126-140. https://doi.org/10.1016/S0148-2963(03)00122-X

Gremler, D. D. (1995). The effect of satisfaction, switching costs, and interpersonal bonds on service loyalty.

Gremler, D. D., Gwinner, K. P., \& Brown, S. W. (2001). Generating positive word - of - mouth communication through customer - employee relationships. International Journal of Service Industry Management, 12(1), 44-59. https://doi.org/10.1108/09564230110382763

Grewal, D., Monroe, K. B., \& Krishnan, R. (1998). The effects of price-comparison advertising on buyers' perceptions of acquisition value, transaction value, and behavioral intentions. Journal of Marketing, 62(2), 46. https://doi.org/10.2307/1252160

Grønhaug, K., \& Gilly, M. C. (1991). A transaction cost approach to consumer dissatisfaction and complaint actions. Journal of Economic Psychology, 12(1), 165-183. https://doi.org/10.1016/0167-4870(91)90048-X

Guiltinan, J. P. (1989). A classification of switching costs with implications for relationship marketing. In AMA winter educators' conference: Marketing theory and practice (pp. 216-220). Chicago: American Medical Association.

Gummesson, E. (2004). Return on Relationships (ROR): The value of relationship marketing and CRM in business - to - business contexts. Journal of Business \& Industrial Marketing, 19(2), 136-148. https://doi.org/10.1108/08858620410524016

Gupta, S., Lehmann, D. R., \& Stuart, J. A. (2004). Valuing customers. Journal of Marketing Research, 41(1), 7-18. https://doi.org/10.1509/jmkr.41.1.7.25084

Hakansson, H. (1982). International marketing and purchasing of industrial goods. IMP Project Group. Wiley and Sons.

Harker, M. J., \& Egan, J. (2006). The past, present, and future of relationship marketing. Journal of Marketing Management, 22(1-2), 215-242. https://doi.org/10.1362/026725706776022326

Heide, J. B., \& Weiss, A. M. (1995). Vendor consideration and switching behavior for buyers in high-technology markets. Journal of Marketing, 59(3), 30-43. https://doi.org/10.2307/1252117

Heskett, J. L., Jones, T. O., Loveman, G. W., Sasser, W. E., \& Schlesinger, L. A. (1994). Putting the service-profit chain to work. Harvard Business Review, 72(2), 164-174. Retrieved from https://hbr.org/2008/07/putting-the-service-profit-chain-to-work

Hewett, K., Money, R. B., \& Sharma, S. (2002). An exploration of the moderating role of buyer corporate culture in industrial buyer-seller relationships. Journal of the Academy of Marketing Science, 30(3), 229-239. https://doi.org/10.1177/0092070302303004

Himanka, L. (2017). Relationship building in cross-cultural business-to-business context. The University of Oulu. Retrieved from http://jultika.oulu.fi/files/nbnfioulu-201705312240.pdf

Hollyoake, M. (2009). The four pillars: Developing a 'bonded' business-to-business customer experience. Journal of Database Marketing \& Customer Strategy Management, 16(2), 132-158. https://doi.org/10.1057/dbm.2009.14

Jap, S. D., \& Ganesan, S. (2000). Control mechanisms and the relationship life cycle: Implications for safeguarding specific investments and developing commitment. Journal of Marketing Research, 37(2), 227-245. https://doi.org/10.1509/jmkr.37.2.227.18735

Jones, M. A., Mothersbaugh, D. L., \& Beatty, S. E. (2000). Switching barriers and repurchase intentions in services. Journal of Retailing, 76(2), 259-274. https://doi.org/10.1016/S0022-4359(00)00024-5

Jones, M. A., Mothersbaugh, D. L., \& Beatty, S. E. (2002). Why customers stay: measuring the underlying dimensions of services switching costs and managing their differential strategic outcomes. Journal of Business Research, 55(6), 441-450. https://doi.org/10.1016/S0148-2963(00)00168-5 
Jones, M. A., Reynolds, K. E., Mothersbaugh, D. L., \& Beatty, S. E. (2007). The positive and negative effects of switching costs on relational outcomes. Journal of Service Research, 9(4), 335-355. https://doi.org/10.1177/1094670507299382

Joseph, M. S., \& Unnikrishnan, A. (2016). Relationship bonding strategies and customer retention: A study in business to business context. IOSR Journal of Business and Management, 38-44. Retrieved from https://pdfs.semanticscholar.org/1f14/07e848838846a7a2743485427b49f28ee8e8.pdf

Kim, M., Kliger, D., \& Vale, B. (2003). Estimating switching costs: The case of banking. Journal of Financial Intermediation, 12(1), 25-56. https://doi.org/10.1016/S1042-9573(02)00005-0

Klemperer, P. (1995). Competition when consumers have switching costs: An overview with applications to industrial organization, macroeconomics, and international trade. The Review of Economic Studies, 62(4), 515-539. https://doi.org/10.2307/2298075

Konhäuser, A. (2007). Understanding value in B2B buyer-seller relationships: Do matching expectations improve relationship strength? Auckland University of Technology. Retrieved from http://hdl.handle.net/10292/150

Kotler, P. (2005). The role played by the broadening of marketing movement in the history of marketing thought. Journal of Public Policy \& Marketing, 24(1), 114-116. https://doi.org/10.1509/jppm.24.1.114.63903

KPMG-Nunwood. (2017). B2B customer experience: Winning in the moments that matter. Retrieved from https://assets.kpmg.com/content/dam/kpmg/uk/pdf/2017/05/b2b-customer-experience-report.pdf

Lam, S. Y., Shankar, V., Erramilli, M. K., \& Murthy, B. (2004). Customer value, satisfaction, loyalty, and switching costs: An illustration from a business-to-business service context. Journal of the Academy of Marketing Science, 32(3), 293-311. https://doi.org/10.1177/0092070304263330

Lapierre, J. (2000). Customer - perceived value in industrial contexts. Journal of Business \& Industrial Marketing, 15(2/3), 122-145. https://doi.org/10.1108/08858620010316831

Li, E., Tseng, P. T. Y., \& Lu, E. (2007). Measuring the strength of partner relationship in B2B EC: An exploratory research. In 2007 International Conference on Wireless Communications, Networking and Mobile Computing (pp. 6732-6737). IEEE. https://doi.org/10.1109/WICOM.2007.1653

Liljander, V., \& Strandvik, T. (1995). The nature of customer relationships in services. Advances in Services Marketing and Management, 4(141), 67. Retrieved from https://pdfs.semanticscholar.org/c2e3/900182191fcfbfe9ad2baa69567e2540170f.pdf

Linde, T., \& Holmqvist, M. (2011). The management of a distributor in a B2B perspective: A case study of Getinge $A B$. Lund University. Retrieved from http://lup.lub.lu.se/student-papers/record/1981300

Lindgreen, A., \& Wynstra, F. (2005). Value in business markets: What do we know? Where are we going? Industrial Marketing Management, 34(7), 732-748. https://doi.org/10.1016/j.indmarman.2005.01.001

Liu, A. H. (2006). Customer value and switching costs in business services: Developing exit barriers through strategic value management. Journal of Business \& Industrial Marketing, 21(1), 30-37. https://doi.org/10.1108/08858620610643157

McMullan, R., \& Gilmore, A. (2008). Customer loyalty: An empirical study. European Journal of Marketing, 42(9/10), 1084-1094. https://doi.org/10.1108/03090560810891154

Möller, K. E. K., \& Törrönen, P. (2003). Business suppliers' value creation potential: A capability-based analysis. Industrial Marketing Management, $\quad 32(2), \quad 109-118$. https://doi.org/https://doi.org/10.1016/S0019-8501(02)00225-0

Müller, K., \& Wilson, D. T. (1988). Interaction perspective in business marketing: An exploratory contingency framework. Pennsylvania.

Mummalaneni, V. (1987). The influence of a close personal relationship between the buyer and the seller on the continued stability of their role relationship. The Pennsylvania State University.

Narteh, B., Agbemabiese, G. C., Kodua, P., \& Braimah, M. (2013). Relationship Marketing and Customer Loyalty: Evidence from the Ghanaian Luxury Hotel Industry. Journal of Hospitality Marketing \& Management, 22(4), 407-436. https://doi.org/10.1080/19368623.2012.660564

Oh, H. (2003). Price fairness and its asymmetric effects on overall price, quality, and value judgments: the case of an upscale hotel. Tourism Management, 24(4), 387-399. https://doi.org/10.1016/S0261-5177(02)00109-7 
Oliver, R. L. (1993). Cognitive, affective, and attribute bases of the satisfaction response. Journal of Consumer Research, 20(3), 418. https://doi.org/10.1086/209358

Parasuraman, A. (1997). Reflections on gaining competitive advantage through customer value. Journal of the Academy of Marketing Science, 25(2), 154-161. https://doi.org/10.1007/BF02894351

Parasuraman, A., \& Grewal, D. (2000). The impact of technology on the quality-value-loyalty chain: A research agenda. Journal of the Academy of Marketing Science, 28(1), 168-174. https://doi.org/10.1177/0092070300281015

Pine II, B. J., Peppers, D., \& Rogers, M. (1995). Do you want to keep your customers forever? Harvard Business Review, 73(March-April), 103-113. $\quad$ Retrieved from https://hbr.org/1995/03/do-you-want-to-keep-your-customers-forever

Pick, D., \& Eisend, M. (2014). Buyers' perceived switching costs and switching: A meta-analytic assessment of their antecedents. Journal of the Academy of Marketing Science, 42(2), 186-204. https://doi.org/10.1007/s11747-013-0349-2

Rauyruen, P., \& Miller, K. E. (2007). Relationship quality as a predictor of B2B customer loyalty. Journal of Business Research, 60(1), 21-31. https://doi.org/10.1016/j.jbusres.2005.11.006

Ravald, A., \& Grönroos, C. (1996). The value concept and relationship marketing. European Journal of Marketing, 30(2), 19-30. https://doi.org/10.1108/03090569610106626

Reichheld, F. F., Markey, R. G. J., \& Hopton, C. (2000). The loyalty effect-the relationship between loyalty and profits. European Business Journal, 12(3), 134-139. Retrieved from https://search.proquest.com/docview/205202641? accountid=32819

Reinartz, W., \& Kumar, V. (2002). The mismanagement of customer loyalty. Harvard Business Review, 80(7), 86-95. Retrieved from https://hbr.org/2002/07/the-mismanagement-of-customer-loyalty

Rust, R. T., Danaher, P. J., \& Varki, S. (2000). Using service quality data for competitive marketing decisions. International Journal of Service Industry Management, 11(5), 438-469. https://doi.org/10.1108/09564230010360173

Selnes, F. (1993). An examination of the effect of product performance on brand reputation, satisfaction, and loyalty. European Journal of Marketing, 27(9), 19-35. https://doi.org/10.1108/03090569310043179

Sharma, A., Krishnan, R., \& Grewal, D. (2001). Value creation in markets. Industrial Marketing Management, 30(4), 391-402. https://doi.org/10.1016/S0019-8501(01)00153-5

Sharma, N., \& Patterson, P. G. (1999). The impact of communication effectiveness and service quality on relationship commitment in consumer, professional services. Journal of Services Marketing, 13(2), 151-170. https://doi.org/10.1108/08876049910266059

Sheth, J. N., \& Sharma, A. (1997). Supplier relationships: Emerging issues and challenges. Industrial Marketing Management, 26(2), 91-100. https://doi.org/10.1016/S0019-8501(96)00153-8

Simpson, P. M., Siguaw, J. A., \& Baker, T. L. (2001). A model of value creation. Industrial Marketing Management, 30(2), 119-134. https://doi.org/10.1016/S0019-8501(00)00138-3

Smith, B. (2009). Buyer-seller relationships: Bonds, relationship management, and sex-type. Canadian Journal of Administrative Sciences / Revue Canadienne Des Sciences de l'Administration, 15(1), 76-92. https://doi.org/10.1111/j.1936-4490.1998.tb00153.x

Stender, M., \& Ritz, T. (2006). Modeling of B2B mobile commerce processes. International Journal of Production Economics, 101(1), 128-139. https://doi.org/10.1016/j.jpe.2005.05.017

Ulaga, W., \& Eggert, A. (2006). Value-based differentiation in business relationships: Gaining and sustaining key supplier status. Journal of Marketing, 70(1), 119-136. https://doi.org/10.1509/jmkg.2006.70.1.119

Ural, T. (2009). The effects of relationship quality on export performance. European Journal of Marketing, 43(1/2), 139-168. https://doi.org/10.1108/03090560910923274

Walter, A., Mueller, T. A., \& Helfert, G. (2000). The impact of satisfaction, trust, and relationship value on commitment: Theoretical considerations and empirical results. In IMP Conference Proceedings (pp. 07-09). Bath, United Kingdom. Retrieved from http://www.impgroup.org/uploads/papers/131.pdf 
Walter, A., Ritter, T., \& Gemünden, H. G. (2001). Value creation in buyer-seller relationships: Theoretical considerations and empirical results from a supplier's perspective. Industrial Marketing Management, 30(4), 365-377. https://doi.org/https://doi.org/10.1016/S0019-8501(01)00156-0

White, L., \& Yanamandram, V. (2007). A model of customer retention of dissatisfied business services customers. Managing Service Quality: An International Journal, 17(3), 298-316. https://doi.org/10.1108/09604520710744317

Wilson, D. T. (1995). An integrated model of buyer-seller relationships. Journal of the Academy of Marketing Science, 23(4), 335-345. https://doi.org/10.1177/009207039502300414

Wilson, D. T., \& Mummalaneni, V. (1986). Bonding and commitment in buyer-seller relationships: A preliminary conceptualization. Industrial Marketing and Purchasing, 1(3), 44-58.

Wilson, D. T., \& Mummalaneni, V. (1990). Buyer-seller relationships as a bonding process: A preliminary conceptualization. The Pennsylvania State University.

Woodruff, R. B. (1997). Customer value: The next source for competitive advantage. Journal of the Academy of Marketing Science, 25(2), 139-153. https://doi.org/10.1007/BF02894350

Wulf, K. De, Odekerken-Schröder, G., \& Iacobucci, D. (2001). Investments in consumer relationships: A cross-country and cross-industry exploration. Journal of Marketing, 65(4), 33-50. https://doi.org/10.1509/jmkg.65.4.33.18386

Zeithaml, V. A. (1988). Consumer perceptions of price, quality, and value: A means-end model and synthesis of evidence. Journal of Marketing, 52(3), 2. https://doi.org/10.2307/1251446

Zeithaml, V. A. (2000). Service quality, profitability, and the economic worth of customers: What we know and what we need to learn. Journal of the Academy of Marketing Science, 28(1), 67-85. https://doi.org/10.1177/0092070300281007

\section{Copyrights}

Copyright for this article is retained by the author, with first publication rights granted to the journal.

This is an open-access article distributed under the terms and conditions of the Creative Commons Attribution license (http://creativecommons.org/licenses/by/4.0/). 